Çifci, M. ve Kaplan, K. (2020). Karikatürde yer alan kırılma çizgilerinin söz sanatları öğretimine etkisi. Ana Dili Eğitimi Dergisi, 8(2), 509-527.

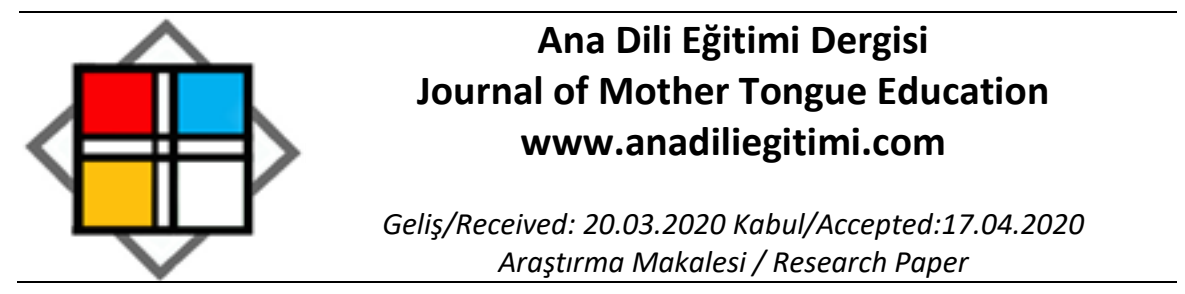

\title{
Karikatürde Yer Alan Kırılma Çizgilerinin Söz Sanatları Öğretimine Etkisi *
}

\author{
Musa ÇiFCi*** \\ Kadir KAPLAN ${ }^{* * * *}$
}

\begin{abstract}
Öz
Çalışmada söz sanatlarının 6. sınıf öğrencilerine öğretilmesinde karikatürdeki kırılma çizgilerinin etkisini belirlemek amaçlanmıştır. Bu doğrultuda söz sanatlarının kırılma çizgileriyle ilişkilendirilerek işlendiği deney grubuyla geleneksel öğretim yönteminin uygulandığı kontrol grubunun ön-sontest puan ortalamalarında hem grup içinde hem de gruplar arasında anlamlı bir fark olup olmadığı ve deney grubu öğrencilerinin sürece ilişkin görüşleri incelenmiştir. Tamamlayıcı karma desen kullanılan araştırmanın nicel boyutu için veri toplama aracı olarak akademik başarı testi; nitel boyutu için de yarı yapılandııııış görüşme formu kullanılımışır. Çalışmada deney ve kontrol grubunda yer alan öğrencilerin öntestten aldıkları puan ortalamalarının anlamlı bir şekilde farklılaşmadığı, deney grubunda yer alan öğrencilerin ön-sontestten aldıkları puan ortalamalarının anlamlı bir şekilde farkılıaştığı, kontrol grubunda yer alan öğrencilerin ön-sontestten aldıkları puan ortalamalarının anlamlı bir şekilde farklılaşmadığl; deney grubundaki öğrencilerin görüşlerinin; uygulama süreci ile ilgili görüşler, uygulama öncesi ve sonrasına yönelik olumlu ve olumsuz düşünceler olmak üzere iki kategoride toplandığı görülmüştür.
\end{abstract}

Anahtar Kelimeler: Karikatür, karikatür okuryazarlığı, söz sanatları, kırılma çizgisi

\section{The Effect of Fracture Lines in the Cartoon on the Teaching of the Rhetorics}

\begin{abstract}
In order to determine the effect of the breaking lines in the cartoon in the teaching of the 6th grade students, the presence of a significant difference in the pre-posttest point averages of the control group, where the traditional teaching method is applied, and the experimental group, in which the rhetorics are associated with the breaking lines, and the experimental group students' process opinions were examined. Academic achievement test as a data collection tool for the quantitative; semi-structured interview form was used for its qualitative dimension. The mean scores of the students in the experimental and control groups did not differ significantly, the mean scores of the students in the experimental group differed significantly from the pre-posttest, and the mean scores of the students in the control group did not differ significantly; opinions of the students in the experimental group; were gathered in two categories as positive and negative.
\end{abstract}

Keywords: Caricature, cartoon literacy, rhetorics, break Line

\footnotetext{
* Uşak Üniversitesi Sosyal Bilimler Enstitüsü Türkçe Eğitimi Doktora Programı dahilinde yürütülmekte olan Ortaokul Türkçe Derslerinde Karikatür Okuryazarlığı Becerisinin Geliştirilmesi: Bir Eylem Araştırması isimli doktora tezinden üretilmiştir.

*** Prof. Dr.; Uşak Üniversitesi, Eğitim Fakültesi, Türkçe ve Sosyal Bilimler Eğitimi Bölümü, Uşak, musa.cifci@usak.edu.tr, ORCID: 0000-0002-3758-7170.

**** Doktora Öğrencisi; Uşak Üniversitesi, Sosyal Bilimler Enstitüsü, Uşak, kadkaplan@gmail.com, ORCID: 00000001-7901-1025
} 


\section{Giriş}

Teknolojik gelişmelere bağlı olarak her alanda yaşanan değişimin eğitim öğretim faaliyetlerini de etkilediği gözlemlenmektedir. Bu gelişmeler, kolay algılama ve kavramayı sağlayıcı görselliği öne çıkarmaktadır. Doğal olarak pek çok görsel unsurun eğitim öğretim etkinliklerinde de yaygın biçimde kullanılmaya çalışıldığı görülmektedir.

Öğrenme, her birey özelinde farklı stillerde gerçekleşmektedir. Bireylerin öğrenmesinde bazen hareket bazen ritim bazen de görseller önemli rol oynamaktadır. Bireyden bireye değişen öğrenme stilindeki farklıık, hem eğitim ortamlarının hem de eğitim ortamlarında kullanılan materyallerin öğrencilerin ilgilerini çekecek biçimde düzenlenmesini gerektirmektedir. Salt bilginin resim, fotoğraf, slayt veya diğer grafik formlar ile desteklenmesi durumunda bazı öğrencilerin daha yüksek öz-yeterlilik yaşadıkları hatta daha yüksek başarıya ulaştıkları görülmektedir (Hawk \& Shah, 2007). Farklı materyallerle desteklenen eğitim öğretim faaliyetleri bireylerin hedeflenen kazanımlara erişmesini kolaylaştırmaktadır; çünkü görsel uyaranlar, eğitim öğretim faaliyetleri sırasında bireylerin birkaç duyu organını aynı anda etkileyerek öğrenme sürecinde aktif rol almalarını sağlamaktadır.

Görsel kullanımının teknolojik gelişmeler ile yaygınlaşması, Türkçe eğitiminde öğrencilerin bireysel farklııklarını da dikkate alarak karikatürlerden de kolayca yararlanma imkânını sağlamıştır. Dil eğitiminde görsel materyaller, öğrenme sürecinin verimliliğini artıran önemli araçlardandır. Hem ders öncesinde hem de ders sırasında motivasyonu sağlamak, ön bilgileri harekete geçirmek, soyut bilgiyi somutlaştırmak amacıyla görsellerden faydalanılmaktadır. Bu noktada Türkçe eğitiminde materyal olarak kullanılabilecek görsel uyaranlardan biri de karikatürlerdir.

Eğitim öğretim faaliyetlerinde görsel okuma becerisine yönelik kullanılan pek çok materyal bulunmaktadır. Bireylerin görsel okuryazarlık becerilerini kazanabilmelerine yönelik yapılan çalışmalarda; resim, şema, grafik, televizyon, bilgisayar, film, kukla, resimli kitap, fotoğraf, poster, harita, bülten tahtası, broşür, model vb. araç gereçler kullanılabilmektedir.

Yapılan çalışmalar incelendiğinde alanyazında karikatürün farklı biçimde tanımlandığı görülmektedir. Abartılmış insan portresinden çizgi odaklı görsel iletişim sanatına (Hünerli, 1993; Aşıcıoğlu, 2001) kadar pek çok tanımı yapılan karikatür tanımlarında dikkat çeken ortak nokta ise abartı ve mizahtır; çünkü karikatür, insanı ya da olayı abartarak çizip ona mizahi bir boyut katmaktadır. Ana Britannica'da (1994) karikatür; kişi ya da olayların gülünç, çelişkili yanlarının abartılı çizgilerle mizaha dönüştürme sanatı olarak tanımlanmakta ve karikatürün zıtlık boyutu da vurgulanmaktadır. Özden (2005) ise güncel olay ya da konuyu iğneleyen, istihza eden veya abartan çizgi resim olarak tanımlayarak karikatürün alay ve kinaye boyutunu öne çıkarmaktadır.

\section{Karikatürün Eğitim Ortamında Kullanımı}

Eğitimin amacı, bireyleri ilgi ve yetenekleri doğrultusunda geliştirmektir. Öğretici konumundaki bireyler, bu amaca ulaşabilmek için eğitim öğretim faaliyetleri sırasında materyal kullanma ihtiyacı duymaktadır. Eğitimle ilgili yapılan araştırmalar (Güneş, 2017), öğretici tarafından seçilecek materyallerde öğrenmenin eğlendirici yanının desteklenmesinin gerekli olduğunu savunmaktadır.

Teknolojik gelişmelerle birlikte görsel materyal kullanımına yönelik ilgi artmasına rağmen barındırdığı olumsuz çağrışımlar sebebiyle karikatür ile eğitim arasındaki ilişki yıllarca fark edilememiştir (Kelley, 1989). Zamanla eğitimin amacı doğrultusunda evrilen karikatür, eğitim öğretim faaliyetlerinde dikkate değer boyutta yer almaya başlamıştır. Keogh \& Naylor (1999), karikatürlerin eğitimde okuma becerilerini geliştirme, kelime bilgisini artırma, problem çözme ve düşünme becerilerini geliştirme, motivasyon sağlama amacıyla kullanılabileceğini ifade ederek karikatürün eğitim alanlarında kullanımının ne kadar yaygın olduğunu ortaya koymuştur.

Karikatürü diğer materyallerden ayıran özelliklerin başında direkt göze hitap etmesi, dikkat çekmede etkili olması (Örs, 2006), amaç doğrultusunda kullanıldığında ele alınan konu ile görsel uyaran arasında bağ kurması $(E f e, 2005)$ gelmektedir. Bunun yanı sıra içeriğinde yer alan ilgi çekici sembollerle öğrencilerde kalıcılığı ve ilgiyi artırması, çocuklar tarafından kolay algılanması (Seçgin, Yalvaç \& Çetin, 2010), öğrencilerin motivasyonunu artırıp olumlu tutum geliştirmelerini sağlaması (Wyk, 2011) da karikatürü öne çıkaran özelliklerdir. Karikatürün sahip olduğu bu özellikler dikkate alındığında amaca 
ve hedef kitleye uygun seçilmiş örneklerle karikatürlerden hem derslerin derse hazırlık çalışmalarında hem de ders işleme ve değerlendirme faaliyetlerinde yararlanabilmektedir.

\section{Türkçe Eğitiminde Karikatür Kullanımı}

Türkçe eğitimi özelinde karikatürün kullanımı ele alındığında görsel materyal olarak karikatürün dört temel beceri ile ilişkilendirilebileceği değerlendirilmektedir.

Dinleme becerisi özelinde karikatürlerden dinleme öncesinde dinlenecek metnin içeriğini karikatürden yararlanarak tahmin etme, dinlenilen metni anlamlandırma, dinlenilen metin ile karikatür arasındaki ilişkiyi değerlendirme noktasında yararlanılabilmektedir. Konuşma becerisine yönelik etkinliklerde de karikatür materyal olarak kullanılmaktadır. Amaca uygun verilen karikatürler üzerinden yürütülecek hazırlıklı ya da hazırlıksız konuşmalarla bireylerin konuşma becerisinin gelişimi sağlanabilmektedir. Akran \& Kocaman'ın (2018) karikatüre dayalı öğrenme-öğretme modelinin konuşma ve dinleme becerilerine etkisini belirlemeye çalıştığı çalışmasında karikatüre dayalı öğrenmeöğretme modeli etkinlikleri ile öğrencilerin arkadaşlarının etkinliklerini ve açıklamalarını dikkatlice dinledikleri, anlamadıkları ve merak ettikleri konular hakkında sorular sordukları sonucuna varmıştır.

Yazma becerisine yönelik etkinliklerde ise karikatürden faydalanarak duygu ve düşünceleri ifade etmeye, kurmaca metinler oluşturmaya yönelik etkinlikler yapılabilmektedir. Şeref \& Yılmaz (2015), çalışmalarında karikatürün Yemenli öğrencilerin yazma ve konuşma becerilerinin geliştirilmesinde etkili bir araç olduğunu tespit ederek karikatürün yazma becerisine yönelik etkinlikler için alternatif bir materyal olabileceğini ortaya koymuştur.

Karikatürün materyal olarak kullanıldığı temel becerilerden bir diğeri de okumadır. Karikatürü anlamlandırmaya yönelik çalışmalar, okuma becerisine de doğrudan olumlu katkı sağlamaktadır. Okuma becerisinin kelime serveti ile arasındaki ilişki doğrultusunda karikatürün kelime, deyim ve atasözü öğretimindeki etkisine yönelik çalışmalar yapılmıştır. Varışoğlu, Şeref, Gedik, \& Yılmaz (2014) yapmış oldukları adlı çalışmanın sonucunda atasözleri ve deyimlerin öğretiminde karikatürlerin mevcut öğretim programı yaklaşımlarına göre daha etkili olduğunu tespit etmiştir. Bu tespit, atasözlerini ve deyimleri daha iyi bir şekilde anlamlandırabilmelerinde karikatürlerin etkili olduğunu ortaya koymaktadır. 6. sınıf Türkçe ders kitabında (EKOYAY, 2019) yer alan hazırlık çalışmaları bölümünde öğrencilerden verilen karikatürle ilgili düşüncelerini sözlü olarak ifade etmeleri istenmiş ve konuşma becerisini geliştirmede karikatürden yararlanılmıştır.

Karikatürler, temel dil becerilerinde olduğu gibi dil bilgisi konularının öğretiminde de kullanılmaktadır. Soyut olduğu için zorlanılan dil bilgisi konularına yönelik hazırlanacak etkinliklerde karikatürler araç olarak kullanılabilmektedir. Akkaya (2011), bu sayede dil bilgisi öğretiminin ilgi çekici hâle dönüşeceğini ifade ederek karikatürlerin dil bilgisi öğretimindeki etkisini ortaya çıkarmıştır. Sonuç itibarıyla karikatürler, amaca uygun ve doğru şekilde kullanıldığında Türkçe eğitiminin amaçlarına hizmet edecek özelliktedir.

Karikatürün Türkçe eğitiminde materyal olarak kullanılabilecek özellikte olmasından hareketle söz sanatlarının öğretiminde karikatürlerden yararlanılabileceği düşünülmüştür. Bu amaçla yürütülen çalışmada söz sanatlarının öğretiminde materyal olarak karikatür kullanılmıştır. Karikatürün temelini oluşturan kırılma çizgileri ile söz sanatları arasındaki bağ, söz sanatları öğretiminde karikatürün materyal olarak tercih edilmesinde etkili olmuştur.

Karikatürlerde verilen mesajın kavranabilmesi için karikatürlerin çözümlenmesi, karikatürden çıkarım yapılması gerekmektedir. Bu noktada anlamın ortaya çıkmasında rol oynayan ve karikatürün özü kabul edilen kırılma çizgileri devreye girmektedir. Karikatürde yer alan kırılma çizgisinde abartma, zıtlık, gülmece ve düşünce bulunmaktadır. Bireyler, konuyla ilgili var olan birikimlerinden ve karikatürdeki kırılma çizgilerinden yararlanarak karikatürü anlamlandırmaktadır.

Bireylerin karikatürdeki iletiyi kavrayabilmesi için karikatürü anlamlandırması, çözümlemesi, değerlendirmesi gerekmektedir. Bunun için öncelik karikatürün algılanmasındadır. Efe'ye göre (2005), karikatürün algılanma sürecindeki aşamalardan biri de kırılma çizgisidir. Karikatürün algılanma sürecinin başlangıcı görmedir. Görmenin ardından bireyin karikatürden çıkarım yapacağı ikinci aşamaya geçilmektedir. Bu aşamada karikatürün kırılma çizgileri ön plana çıkmaktadır. Kırılma çizgisi karikatürün özü olarak kabul edilmektedir; çünkü karikatürün öğrenmedeki işlevi kırılma çizgisinin 
algılama noktasına dönüşmesiyle gerçekleşmektedir. Kırılma çizgisinin içeriğinde abartma, zıtlık, gülmece ve düşünce bulunmaktadır. Bu aşamada birey, sahip olduğu yaş ve kültürel özellik ve var olan birikiminden hareketle algılama noktası oluşturarak karikatür diliyle okuma yapmakta ve karikatürü anlamlandırmaktadır.

Karikatürlerde ele alınan konu ya da olay, dikkat çekme, farkındalık oluşturma, eleştirme veya hicvetme amacıyla abartılı bir biçimde karikatür çizeri tarafından ele alınır. Kırılma çizgisi olarak abartının kullanımı karikatür çizerinin vermek istediği iletinin hedef kitle tarafından anlaşıırlığını kolaylaştırmaktadır.

\section{Söz Sanatları}

Söz sanatları için dilin zenginliği denilebilir; çünkü söz sanatları aracılığıyla eserlerin etkileyiciliği artırılabilmektedir. Bireyler duygu, düşünce ve durumlarını etkili ve güzel bir şekilde ifade edebilmek için her türlü anlama ve anlatma faaliyetinde kelimelerin sanatlı hâllerini kullanılabilmektedirler.

Sembolik anlamları ifade etmek, farklı anlam ilgileri kurmak amacıyla üretilen söz sanatları; Türk edebiyatının ilk devirlerinden bu yana kullanılmış olup günümüzde de her türden sürekli ya da süreksiz metinlerde, günlük konuşmalarda fazlaca kullanılmaktadır.

Söz sanatları dilin estetik boyutunun temsilinde önemli bir yere sahiptir. Söz sanatlarının tasnifi noktasında farklı görüşler bulunmaktadır. Aktaş (2002), söz sanatlarını mecazla ilgili olanlar (teşbih/benzetme/comparasion, istiare/metaphore, mecaz/trope, mecaz-I mürsel/ metonymie/synecdoque, kinaye/allusion, tariz/insination), düşünceyle ilgili olanlar (tezat/ antitese/ karşıtlık, istihdam, tevriye, tecahül-i arif, müşakale, teşhis/ personnification/ kişileştirme, intak, hüsn-i talil, mübalağa/ abartma/ hyperbole, tekellüm-i ruh), heyecanla ilgili olanlar (nida/ exclamation, terdid/ disfonction, kat/ reticence, rücu/ correction, iltifat/ apostrophe, tekrir/ anaphore, tedric/ gradation/ dereceleme, istifham/ interrogation), bilgiyle ilgili olanlar (telmih, iktibas, muamma, lügaz, mülemma, irsal-i mesel), anlamla ilgili olanlar (iham, tenasüb, lefu ü neşir, sihr-i helal, ibham, tehzil), sözle ilgili olanlar (cinas, iştikak, iade, akis), harf ve yazıyla ilgili olanlar (akrostiş, lebdeğmez, aliterasyon, tarih düşürme) olarak ayırır.

Çotuksöken (2012) ise söz ve anlam sanatları olarak ayırdığı söz sanatlarını benzetme (teşbih), eğretileme (istiare), bilmezlikten gelme (tecahüliarif), mecaz (değişmece), güzel nedenleme (hüsnitalil), karşıtlık (tezat), tenasüp, tevriye, beklenmezlik (terdit), anıştırma (telmih), abartma (mübalağa) olarak tasniflemektedir.

\section{Türkçe Eğitiminde Söz Sanatları}

Dil eğitimindeki amaçlardan biri de duygu ve düşünceleri sözlü ya da yazılı olarak ifade etmektir. Söz sanatları, bireylere kendilerini, duygu, düşünce ve isteklerini daha çarpıcı, güzel, etkili, yaratıcı ve sanatı biçimde aktarma fırsatı sunmaktadır. Anlama kattığı zenginlik sebebiyle söz sanatlarına Türkçe eğitiminde yer verilmektedir.

Aslan, Güldenoğlu ve Altundaş (2018), Türkçe dersi ile söz sanatları arasındaki bağa Türkçe derslerinin çoğunlukla yazınsal metinler üzerinden yürüdüğünü belirterek söz sanatlarının metne kattığı anlamları anlamaya ve anlamlandırmaya dayalı çalışmaların öğrenciler için bir nevi soyut olanı çözümleme ve metnin anlam evrenine girme olduğunu vurgular.

Öğrencilerin okudukları metindeki anlamı yakalayıp metni anlamlandırabilmeleri söz sanatlarının metne olan katkısını fark etmelerine bağlıdır. Böylece öğrenci sanatın metne olan etkisini yakaladığı gibi metni anlama noktasında da herhangi sıkıntı yaşamayacaktır.

Aynı şekilde yazma becerisine yönelik yürütülen çalışmalarda öğrenciler anlatımlarını zenginleştirmek, sözün etkisini artırmak amacıyla oluşturdukları metinlerde söz sanatlarına yer vererek oluşturdukları ürünlerin hem estetik bakımdan hem de anlam bakımından zenginleşmesini sağlayacaktır.

Söz sanatları, yazılı ürünleri anlam olarak zenginleştirdiği gibi konuşma dilini de zenginleştirmektedir. Böylece sözün etkisi artmakta, öğrencinin vermek istediği sözlü ileti hedef kitle tarafından kolaylıkla anlaşılabilmektedir. 
Söz sanatlarının anlama olan etkisini fark edip benimseyen öğrenciler, okudukları metinlerin iletilerini daha iyi anladığı gibi dinledikleri metinlerin iletilerini de doğru bir şekilde anlayacaktır. Söz sanatları ile temel dil becerileri arasındaki ilişkiden yola çıkarak Türkçe derslerinde anlama ve anlatma çalışmalarında öğrencilerin yaş ve gelişim özelliklerine uygun olacak şekilde söz sanatlarından yararlanılabileceği söylenebilir. Türkçe Dersi Öğretim Programı'nda (MEB, 2019) "Tema ve Konu Önerileri" nde "Sanat" başlığında söz sanatları konusunun tavsiye edildiği görülmektedir. Söz sanatlarıyla ilgili kazanımlara baktığımızda $1,2,3$ ve 4 . sınıflarda doğrudan söz sanatlarına yönelik kazanım olmadığı; 5,6,7 ve 8 . sınıflarda söz sanatlarının okuma becerisinde yer alan anlama ve söz varlığı başlıkları altında verildiği görülmektedir.

Tablo 1.

Söz Sanatlarının Sınıf Seviyelerine Dağııımı

\begin{tabular}{|c|c|c|c|}
\hline $\begin{array}{l}\text { Sinıf } \\
\text { Seviyesi }\end{array}$ & Dil Becerisi & Kazanım & Kazanım Açıklaması \\
\hline 5 & Okuma/Anlama & $\begin{array}{l}\text { T.5.3.32. Metindeki söz } \\
\text { sanatlarını tespit eder. }\end{array}$ & $\begin{array}{l}\text { Benzetme (teşbih) ve kişileştirme } \\
\text { (teşhis) söz sanatları verilir. }\end{array}$ \\
\hline 6 & Okuma /Anlama & $\begin{array}{l}\text { T.6.3.14. Metindeki söz } \\
\text { sanatlarını tespit eder. }\end{array}$ & $\begin{array}{l}\text { Konuşturma (intak) ve karşıtlık } \\
\text { (tezat) söz sanatları verilir. }\end{array}$ \\
\hline 7 & Okuma /Söz Varlığı & $\begin{array}{l}\text { T.7.3.8. Metindeki söz } \\
\text { sanatlarını tespit eder. }\end{array}$ & $\begin{array}{l}\text { Kişileştirme (teşhis), konuşturma } \\
\text { (intak), karşıtlık (tezat) ve abartma } \\
\text { (mübalağa) söz sanatları verilir. }\end{array}$ \\
\hline 8 & Okuma /Söz Varlığı & $\begin{array}{l}\text { T.8.3.7. Metindeki söz } \\
\text { sanatlarını tespit eder. }\end{array}$ & $\begin{array}{l}\text { Benzetme (teşbih), kişileştirme } \\
\text { (teşhis), konuşturma (intak) ve } \\
\text { karşıtlık (tezat), abartma (mübalağa) } \\
\text { söz sanatlarının belirlenmesi } \\
\text { sağlanır. }\end{array}$ \\
\hline
\end{tabular}

Tablo incelendiğinde söz sanatlarının anlama olan etkisinin göz önüne alınarak okuma becerisiyle ilişkilendirildiği görülmektedir. Türkçe Dersi Öğretim Programı'nda benzetme, kişileştirme, konuşturma, karşıtlık ve abartma sanatlarının tespit edilmesi hedeflenmektedir. "Metindeki söz sanatlarını tespit eder." kazanımı altındaki terimlerin sınıftan sınıfa farklılık gösterdiği anlaşılmaktadır. Kazanıma ait açıklamalarda söz sanatları sınıflara şöyle dağıtılmıştır: Benzetme ve kişileştirme (5. Sınıf), konuşturma ve karşıtık (6. sınıf), kişileştirme, konuşturma, karşıtlık ve abartma (7. sınıf), benzetme, kişileştirme, konuşturma, karşıtık, abartma (8. sınıf). Bu dağıtımla daha önce öğrenilmiş söz sanatlarının pekiştirilmeye çalışıldığını söylemek mümkündür. Bu kapsamda Türkçe Dersi Öğretim Programı́nda yer alan söz sanatları genel olarak incelenmiştir.

\section{Benzetme}

Benzetme; sözü etkili kılmak, sözün anlaşııılığını artırmak amacıyla aralarında farklı yönlerden anlam ilgisi olan iki unsurdan nitelikçe zayıf olanın güçlü olana yaklaştırılmasıdır. Bilgin (2013), benzetmenin olması için aralarında ortak özellikleri bulunan kavramların karşılaştırılması gerektiğini belirtmektedir. Özellikle konuşma ve yazma etkinliklerinde sıkça kullanılan (Onan, 2013) benzetmenin benzeyen, benzetilen, benzetme yönü ve benzetme edatı olmak üzere dört unsuru bulunmakta ve dil öğretim çalışmalarında sıkça kullanılmaktadır.

\section{Kişileştirme}

Insana ait özelliklerin insan dışında kalan canlı ya da cansız varlık veya kavramlara yüklenmesi, aktarılmasıdır. Kocakaplan (1992) bitki, hayvan ya da canlı olmayan bir varlı̆ın insana benzetilmesinin kişileştirme sanatını ortaya çıkardığını belirterek benzetme sanatı ile kişileştirme arasında ilişki kurmaktadır. Kişileştirmede de temel amaç anlatımı etkili kılmaktır. 


\section{Konuşturma (intak)}

İnsan dışı varlıkların insan özelliği kazanıp konuşturulmasına intak denmektedir. Bu sebeple konuşturma sanatının olduğu her yerde kişileştirme sanatı da bulunmaktadır. Konuşturma sanatının gerçekleşebilmesi için varlıkların ağzından söz çıkması gerekmektedir; aksi takdirde konuşturma sanatı değil, kişileştirme sanatı yapılmış olacaktır.

\section{Karşıtık/ Zıtık (Tezat)}

Zıtlık; aralarında ilgi bulunan karşıt iki kavram, durum, duygu, olgu, düşünce ya da olaya ait nitelikleri bir arada dile getirmektir. Zıtlık sanatında amaç, kavramların daha iyi bilinmesini, anlaşıımasını sağlamaktır. Kocakaplan (1992), karşıtlık sanatı ile ifadelerin anlam genişliği, zenginliği kazanacağını ifade ederek karşıtık sanatının etkisini ortaya koymaktadır. Aksan (2001) da zıtlık söz sanatının etkisine dair önermenin yanına ona zıt olan beklenmeyen bir başkasının getirilmesinin metin çözücü için şaşırtıcı olmakla birlikte metnin etkisini artırdı̆̆ını belirtir.

\section{Abartma (Mübalağa)}

Mevcut bir durumu olduğundan daha fazla ya da daha az göstermeye abartma denmektedir. Abartma, sözün etkisini artırmak amacıyla var olanı, olduğundan çok ya da noksan göstermektir. Metnin anlatımını ve bireyleri etkilemeyi hedeflediğinden yaygın bir kullanım alanı bulunmaktadır.

Aslan, Güldenoğlu \& Altuntaş'a göre (2018) öğrencilerin dili başarılı ve yetkin bir biçimde kullanabilmesi için söz sanatlarının sıklıkla geçtiği yazınsal niteliği yüksek metinlerle buluşturulması, metindeki söz sanatlarını anlayabilecekleri ortamlar oluşturulması, söz sanatlarının anlamı nasıl zenginleştirdiği sezdirilmesi ve tüm bu hedeflere uygun araç gereçler kullanılması gerekmektedir. Bu noktada söz sanatlarının daha etkili ve işlevsel materyaller kullanılarak öğretilmesi onu geleneksel yöntemlerden kurtaracak, bilgi ve tanım düzeyinde kalmasına da engel olacaktır.

Yapılan araştırmalar söz sanatlarının öğretiminde yaratıcı dramadan (Uludağ, 2018), görsel materyallerden (Coşar, 2005), simgesel dil kullanımından (Akkuş, 2011) faydalanılabileceğini ortaya koymaktadır. Çalışmayı destekleyen bir araştırmanın (Betur, 2019) sonuçlarına göre öğrenciler söz sanatlarının öğretimi noktasında ders kitabındaki açıklama, etkinlik ve örneklerin yetersiz olduğunu belirtmektedir. Bu tespitten hareketle metnin anlamına doğrudan katkı sağlayan söz sanatlarının kurallarını bilmek, metnin içerisinde söz sanatını tespit etmek yerine öğrencilerin söz sanatlarııın anlama olan etkisini fark ettirecek etkinliklere ve materyallere intiyaç duyduğu görülmektedir. Çalışmanın önemi de bu noktada ortaya çıkmaktadır. Çalışmada söz sanatlarının öğretilmesinde karikatürlerin temelini oluşturan kırılma çizgilerinin etkisini belirlemek hedeflenmiştir. Bu sayede söz sanatlarının öğretilmesinde kullanılan geleneksel yöntemler yerine öğrencilerin ilgisini çekerek onların motivasyonlarını artıracak, daha işlevsel materyal konumundaki karikatürler ders materyali kullanılacak bu da söz sanatları konusunun bilgi ve tanım düzeyinde kalmasına engel olup bilgi ve becerinin kalıcı olmasını sağlayacaktır. Çalışmada söz sanatlarının öğretilmesinde karikatürlerin temelini oluşturan kırılma çizgilerinin etkisini belirlemek amacıyla aşağıdaki sorulara yanıt aranmıştır:

1. Söz sanatlarının karikatürdeki kırılma çizgileri ile ilişkilendirilerek işlendiği deney grubu ile geleneksel öğretim yönteminin uygulandığı kontrol grubunun öntest puan ortalamaları arasında anlamlı bir farklılık var mıdır?

2. Söz sanatlarının karikatürdeki kırılma çizgileri ile ilişkilendirilerek işlendiği deney grubu ile geleneksel öğretim yönteminin uygulandığı kontrol grubunun son test puan ortalamaları arasında anlamlı bir farklııı var mıdır?

3. Söz sanatlarının karikatürdeki kırılma çizgileri ile ilişkilendirilerek işlendiği deney grubunun ön-sontest puan ortalamaları arasında anlamlı bir farklılık var mıdır?

4. Geleneksel öğretim yönteminin uygulandığı kontrol grubunun ön-sontest test puan ortalamaları arasında anlamlı bir farklılık var mıdır?

5. Söz sanatlarının karikatürdeki kırılma çizgileri ile ilişkilendirilerek işlendiği deney grubu öğrencilerinin sürece ilişkin görüşleri nelerdir? 


\section{Yöntem}

Yapılan bu araştırmada söz sanatlarının öğretilmesinde karikatürlerin temelini oluşturan kırılma çizgilerinin etkisini belirlemek için nitel destekli nicel araştırma deseni kullanılmıştır. Tamamlayıcı karma desen olarak adlandırılan bu desende nicel desenden elde edilen bulguların anlamlandırılmasında nitel desenin sonuçlarından da yararlanmak esastır. Baki \& Gökçek (2012), tamamlayıc karma desenin nitel ve nicel verilerin mevcut durumu zenginleştirmek ve ayrıntılı bir hale getirmek için kullanıldığını belirtmektedir. Özetle tamamlayıcı karma desende bulgular yorumlanırken bir desenden elde edilenler diğer desenin sonuçlarını desteklemede kullanılmaktadır.

Çalışmanın nicel boyutu için araştırmanın doğası gereği deneysel araştırma yöntemlerinden yarı deneysel desenlerden öntest-sontest eşleştirilmiş kontrol gruplu desen kullanılmıştır. Söz konusu desende deney ve kontrol grubu belirli bir değişken dikkate alınarak eşleştirilmektedir (Büyüköztürk, Kılıç Çakmak, Akgün, Karadeniz \& Demirel, 2018). Nitel boyut içinse deney grubundan seçilen öğrencilerin sürece ilişkin görüşleri alınmıştır.

\section{Çalışma Grubu}

Araştırmanın çalışma evreni Afyonkarahisar ilindeki 6. sınıf öğrencileridir. Araştırmanın çalışma grubunu, 2019-2020 eğitim-öğretim yılında Afyonkarahisar il merkezinde yer alan bir devlet okulunda öğrenim gören, 14 'ü deney ve 14'ü kontrol grubunda yer alan toplam 28 ortaokul öğrencisi oluşturmaktadır. Araştırmanın amaçları doğrultusunda çalışma grubunun soruna en uygun kesimi örnekleme dâhil edilmek istendiği için çalışmada amaçı̈ı örneklem kullanılmıştır. Amaçlı örneklem çeşitlerinden ise araştırmacının incelediği durumu ortaya çıkarması için kritik önem arz eden durumun varlığı sebebiyle ölçüt örneklemesi kullanılmıştır. Ölçüt örneklemesindeki asıl nokta önceden belirlenmiş bir dizi ölçütü karşılayan durumların çalışılması ve örneklemin bilgi verme açısından zengin olmasıdır (Marshall, 1996). Bu noktada araştırmada belirlenen ölçüt, söz sanatlarının anlamlandırılmasında genel Türkçe ders başarııının etkisi dikkate alınarak araştırmacı tarafından oluşturulmuş, deney ve kontrol grupları 2019-2020 eğitim öğretim yılı 1. dönem Türkçe dersi not ortalamasına (Kontrol grubu: 61,32, Deney grubu: 63,73) göre eşleştirilmiştir.

Tablo 2 .

Örneklem Grubundaki Öğrencilerle ilgili Bilgiler

\begin{tabular}{l|l|l|l}
\hline Grup & Kız & Erkek & Toplam \\
\hline Deney Grubu & 4 & 10 & 14 \\
Kontrol Grubu & 5 & 9 & 14 \\
Toplam & 9 & 19 & 28 \\
\hline
\end{tabular}

Araştırmaya katılan öğrenciler demografik açıdan incelendiğinde örneklemin 9'u (\%32.15) kız, 19'u (\%67.85) erkek öğrenciden oluşmaktadır. Çalışma grubuna deney ve kontrol grubundan on dörder öğrenci olmak üzere toplam 28 öğrenci dâhil edilmiştir.

\section{Veri Toplama Aracı}

Araştırmanın nicel boyutunu oluşturan ilk dört alt problem için Millî Eğitim Bakanlığı Ölçme Değerlendirme ve Sınav Hizmetleri Genel Müdürlüğünün 2015-2019 yılları arasında 6. sınıf öğrencileri için hazırlamış olduğu Türkçe dersi söz sanatları kazanım testleri arasından bilgisayar ortamında yansız (random) olarak seçilen, kapsam olarak benzetme $(f=2)$, kişileştirme $(f=2)$, abartma $(f=2)$, konuşturma $(f=2)$ ve zıtlık ( $f=2)$ sanatlarının yer aldığı ve öğrencilerin daha önce karşılaşmadığı sorulardan oluşan 10 soruluk bir başarı testi kullanılmıştır.

Araştırmanın nitel boyutunu oluşturan beşinci alt problem için deney grubu öğrencilerinin sürece ilişkin görüşlerini belirlemek için de yarı yapılandırılmış görüşme formu kullanılmıştır.

Ölçme aracının güvenirliği ve geçerliğini sağlamak amacıyla oluşturulan 10 soruluk başarı testi, alanında uzman dört Türkçe öğretmeninin görüşüne sunulmuş, onlardan hazırlanan taslak formda yer alan maddelerin kapsam geçerliliğini; ölçme aracının kullanışııı̆ına dair sayfa yapısını, soru ve cevapların dizilişini, yazı formatını ve boyutunu değerlendirmeleri istenerek görüş alınmıştır. 
Değerlendirme sonucu ortaya çıkan ön uygulama formu hedef kitleyle benzer özellikler taşıyan gruba uygulanarak ölçme aracına son şekli verilmiştir. Hazırlanan 10 soruluk test öğrencilere uygulanarak cevaplama süreleri ve anlamakta zorluk çektikleri ifade olup olmadığı kontrol edilmiştir. Öğrencilerin yaklaşık olarak 15 dakikada testi cevaplayabildikleri gözlenmiş ve testin pilot uygulaması yapılmıştır.

Araştırmanın ikinci alt problemi için yarı yapılandırılmış görüşme formu kullanılmıştır. Deney grubunu oluşturan öğrencilerin söz sanatlarının karikatürdeki kırılma çizgileri ile ilişkilendirilerek işlendiği süreci detaylandırmak amacıyla iki sorudan oluşan yarı yapılandırılmış görüşme formu hazırlanmıştır. Görüşme formunda öğrencilere "Söz sanatlarının karikatürdeki kırılma çizgileri ile ilişkilendirilerek işlendiği süreçle ilgili duygu ve düşüncelerinizi belirtiniz.", "Daha önceki Türkçe dersleriniz ile söz sanatlarının karikatürdeki kırılma çizgileri ile ilişkilendirilerek işlendiği Türkçe derslerinizi karşılaştıracak olsanız sürecin olumlu ve olumsuz yönleri hakkında neler söylersiniz?" soruları sorulmuştur.

Yarı yapılandırılmış görüşme formunun amaca uygunluğu, anlaşılırlığı ve kullanılabilirliğini kontrol etmek amacıyla alan uzmanlarından görüş alınmıştır. Alan uzmanların görüşleri doğrultusunda form düzenlenmiştir. İkinci aşamada deney grubu ile benzer özellikler taşıyan gruba pilot uygulama yapıımış, yarı yapılandırılmış görüşme formunda herhangi bir sorun olmadığı görülmüştür. Araştırmada geçerlik ve güvenirlik kapsamında yapılan görüşmelerin süreleri uzun tutularak iç geçerlik sağlanmış ve verilerin inandırıcılığını artırmak için elde edilen bulguların tutarlılığı, kavramsal çerçeve ile uyumu kontrol edilmiştir. Formdan doğrudan alıntılar yapılarak araştırmanın inandırıcılığı artırılmıştır. Araştırmanın dış geçerliği için süreç ayrıntılı bir şekilde betimlenmiştir. Araştırmanın iç güvenirliği için bulgu örnekleri yorum yapılmadan doğrudan verilmiştir. Ayrıca yarı yapılandırılmış görüşmeden elde edilen veriler üzerinde araştırmacılar ayrı ayrı kodlamalar yapmış ve kodlamalar karşılaştırılarak tutarlık oranı hesaplanmıştır. Dış güvenirlik için araştırmanın ham verileri saklanmıştır.

\section{Uygulama Süreci}

Amacı söz sanatlarının öğretilmesinde karikatürlerin temelini oluşturan kırılma çizgilerinin etkisini belirlemek olan çalışma Türkçe dersi kapsamında yürütülmüştür. Uygulama öncesi öğrencilerin 5. sınıfta öğrendikleri benzetme ve kişileştirme sanatları da dahil olmak üzere benzetme, kişileştirme, abartma, konuşturma ve zıtlık söz sanatlarına uygun; kırılma çizgileri ile ilişkilendirilmiş, uygulama sürecinde kullanılacak karikatürler; daha önceden farklı karikatüristler tarafından çizilmiş karikatürler arasından seçilmiştir. Söz sanatlarının öğretilmesinde karikatürlerin temelini oluşturan kırılma çizgilerinin kullanıldığı uygulama süreci 2 ders saati öntest- sontest olmak üzere toplam 6 ders saati olacak şekilde planlanmıştır. Sürecin detayı Tablo 3'te sunulmuştur:

Tablo 3.

Uygulama Takvimi

\begin{tabular}{|c|c|c|}
\hline Grup & Tarih & Etkinlik \\
\hline Deney & \multirow[t]{2}{*}{ 10.02.2020 } & Öntestin Yapılması \\
\hline Kontrol & & Öntestin Yapılması \\
\hline Deney & \multirow[t]{2}{*}{11.02 .2020} & $\begin{array}{l}\text { Benzetme (teşbih), kişileştirme (teşhis), konuşturma (intak) söz } \\
\text { sanatlarının karikatürlerin temelini oluşturan kırılma çizgileri ile } \\
\text { işlenmesi ve Etkinlik-D1 }\end{array}$ \\
\hline Kontrol & & $\begin{array}{l}\text { Benzetme (teşbih), kişileştirme (teşhis), konuşturma (intak) söz } \\
\text { sanatlarının geleneksel yöntemle işlenmesi ve Etkinlik-K1 }\end{array}$ \\
\hline Deney & \multirow[t]{2}{*}{ 13.02.2020 } & $\begin{array}{l}\text { Karşıtlık (tezat), abartma (mübalağa)söz sanatlarının } \\
\text { karikatürlerin temelini oluşturan kırılma çizgileri ile işlenmesi, } \\
\text { Etkinlik-D2 ve Genel Tekrar Etkinliği-D }\end{array}$ \\
\hline Kontrol & & $\begin{array}{l}\text { Karşıtlık (tezat), abartma (mübalağa)söz sanatlarının geleneksel } \\
\text { yöntemle işlenmesi, Etkinlik-K2 ve Genel Tekrar Etkinliği-K }\end{array}$ \\
\hline Deney & \multirow[t]{2}{*}{17.02 .2020} & Sontestin Yapılması \\
\hline Kontrol & & Sontestin Yapılması \\
\hline
\end{tabular}


Söz sanatlarının öğretilmesinde karikatürlerin temelini oluşturan kırılma çizgilerinin kullanıldığı derslerin planları hazırlanmış ve planlarla ilgili uzman görüşü alınmıştır. Alan uzmanlarından alınan dönütlerden sonra karikatürde yer alan kırılma çizgileri ile desteklenmiş etkinlikler hazırlanmıştır. Hazırlanan etkinliklerle ilgili uzman görüşü alınarak etkinliklere son şekli verilmiştir. Son şekli verilen etkinlikler için hedef kitle ile benzer özellikler barındıran bir grupla pilot uygulama yapılmıştır. Pilot uygulama sonrası etkinliklerde herhangi bir sorun olmaması üzerine söz konusu etkinliklerden uygulama sürecinde yararlanılmıştır.

\section{Kontrol Grubu / Süreç}

İlk ders saatinde kontrol grubundaki öğrencilere çalışma ile ilgili genel bilgi verilerek öntest uygulanmıştır.

Kontrol grubunda söz sanatları konusu geleneksel yöntemlerle işlenmiştir. Konunun işlenmesinin ardından Millî Eğitim Bakanlığı Eğitim Bilişim Ağı'nda yer alan etkinlikler pekiştirme amaçlı kullanılmıştır. Uygulama ve etkinliklerin tamamlanmasının ardından sontest uygulanmıştır.

\section{Deney Grubu / Süreç}

İlk derste deney grubundaki öğrencilere söz sanatlarının öğretilmesinde karikatürlerin temelini oluşturan kırılma çizgilerinin kullanılacağı uygulama süreci ile ilgili bilgilendirme yapılarak öntest uygulanmıştır.

Söz sanatlarının öğretilmesinde karikatürlerin temelini oluşturan kırılma çizgilerinin kullanıldığı deney grubunda becerilerin doğrudan öğretim yöntemi kullanılmıştır. Becerilerin doğrudan öğretilmesinde temel nokta hedef kazanımlarla ilgili içeriğin belirli bir düzende sıralanması ve süreç içerisinde öğreticinin öğrenciye rehberlik etmesidir. Doğrudan öğretim modelindeki aşamaları sunuş, model olma, rehberlikli uygulama, dönüt ve düzeltme, bağımsız uygulama ve değerlendirme olarak ayrılmaktadır (Ekergil, 2000). Bu kapsamda deney grubunda yürütülen çalışmayı betimlediğimizde;

Sunuş basamağında dersin amacını öğrencilere ifade edilerek motive olmaları sağlanmıştır. Ardından söz sanatlarının karikatürdeki kırılma çizgilerinden yararlanarak öğretimine geçilmiştir. Bu aşamada kazanılacak becerilere yönelik örnekler gösterilmiştir. Zaman zaman sorulan sorularla söz sanatlarının anlaşıma durumu kontrol edilmiş; ihtiyaç durumunda konuyla ilgili farklı örnekler sunulmuştur.

Model basamağında öğretmen tarafından örnek karikatürler üzerinden söz sanatlarının nasıl tespit edileceğine dair uygulamalar yapılmıştır.

Rehberlikli uygulamada öğrencilere sorumluluk verilmiş, karikatürdeki kırılma çizgilerinden hareketle söz sanatlarını bulmaları sağlanmış; gerekli durumlarda geribildirim yapıımıştır.

Bağımsız uygulama basamağında ise öğrenciler; herhangi ipucu, yardım, rehberlik almadan karikatürdeki kırılma çizgilerinden hareketle söz sanatlarını bulabilecek duruma gelmiştir.

Dönüt ve düzeltme/ölçme ve değerlendirme basamağında söz sanatlarının öğretilmesinde karikatürlerin temelini oluşturan kırılma çizgilerinin kullanımı süreci bir bütün olarak değerlendirilmiştir.

\section{Verilerin Analizi}

Araştırmanın ilk dört alt problemi için hazırlanan 10 soruluk başarı testinden elde edilen veriler SPSS veri analiz programı kullanılarak çözümlenmiştir. Deney ve kontrol gruplarının ön-test, son-test puanları arasında anlamlı farklılık olup olmadığı tespit edilmiştir. Deney grubundaki verilerin normal dağılım göstermesi sebebiyle deney grubunun ön-sontest puan ortalamaları arasındaki farklılık için Bağımlı [ilişkili] Gruplar t-Testi (Paired Samples t-Test); kontrol grubundaki verilerin normal dağılım göstermemesi sebebiyle kontrol grubunun ön-sontest puan ortalamaları arasındaki farklılık için Wilcoxon İ̧̧aretli Sıralar Testi (Wilcoxon Signed Rank Test); gruplar arası normal dağılım göstermesi nedeniyle grupların aralarındaki ön-sontest puan ortalamaları arasındaki farklılık için Bağımsız Gruplar için t- Testi (Independent Samples T Test) uygulanmıştır.

Nicel verileri detaylandırmak, desteklemek için de araştırmanın son alt probleminde deney grubundan 7 öğrenci ile yarı yapılandırılmış görüşme yapılmıştır. Elde edilen verilerin analizinde 
tematik kodlama yapılmıştır. Tematik kodlamada Strauss \& Corbin'in (1998) yaptığı sınıflandırma dikkate alınmış ve verilerden çıkarılan kavramlara göre kodlama yapılmıştır.

\section{Etik Kurulu İzi}

Kurul adı = Uşak Üniversitesi Sosyal ve Beşeri Bilimler Bilimsel Araştırma ve Yayın Etiği Kurulu Karar tarihi $=11 / 10 / 2019$

Belge sayı numarası $=2019-50$

\section{Bulgular}

Araştırmada elde edilen veriler ışığında ulaşılan bulgular, alt problem sırası dikkate alınarak belirtilmiştir.

\section{Birinci Alt Probleme ilişkin Bulgular}

Söz sanatlarının karikatürdeki kırılma çizgileri ile ilişkilendirilerek işlendiği deney grubu ile geleneksel öğretim yönteminin uygulandığı kontrol grubunun puan ortalamaları arasındaki farklılık öncesinde puan ortalamalarının normal dağılım gösterip göstermediği incelenmiştir. KolmogorovSmirnov testi sonuçları değerlendirilmiş, örneklem sayısı 28 kişi olduğu için Shapiro-Wilk sonuçlarına bakılmış; deney ve kontrol gruplarının öntest puan ortalamaları anlamlılık değeri ( $p>0.05)$ olduğundan verilerin normal dağılıma uygun olduğu tespit edilerek Tablo 4'te gösterilmiştir.

Tablo 4.

Deney ve Kontrol Grupları Öntest Puan Ortalamaları Normallik Testi

\begin{tabular}{llllllll} 
& \multicolumn{3}{l}{ Kolmogorov-Smirnov } & \multicolumn{4}{l}{ Shapiro-Wilk } \\
\cline { 2 - 7 } & Statistic & Df & Sig. & Statistic & df & Sig. \\
\hline Toplam Puan Öntest &, 175 & 28 &, 028 &, 952 & 28 &, 219 \\
Toplam Puan Sontest &, 136 & 28 &, 198 &, 939 & 28 &, 105 \\
\hline
\end{tabular}

Söz sanatlarının karikatürdeki kırılma çizgileri ile ilişkilendirilerek işlendiği deney grubu ile geleneksel öğretim yönteminin uygulandığı kontrol grubunun öntest puan ortalamaları arasındaki farklılık Tablo 5'te gösterilmiştir.

Tablo 5.

Deney ve Kontrol Grupları Öntest Puan Ortalamaları

\begin{tabular}{lllllllll}
\hline Grup & $\mathrm{N}$ & Mean & Std. Sapma & Std. Hata Ort. & T & df & p \\
\hline Deney & 14 & 40,71 & 23,685 & 6,330 &,- 341 & 26 &, 736 \\
Kontrol & 14 & 43,57 & 20,609 & 5,508 & & & \\
\hline
\end{tabular}

Tablo 5'te deney ve kontrol grubunda yer alan öğrencilerin öntestten aldıkları puan ortalamaları arasındaki farklılaşmayı tespit etmek için yapılan bağımsız örneklemler grubu t testi sonuçları mevcuttur. Deney ve kontrol grubunda yer alan öğrencilerin öntestten aldıkları puan ortalamaları anlamlı bir şekilde farklılaşmamaktadır (t:-,341, p>.05). Deney grubundaki öğrencilerin öntest puan ortalamaları ( $\bar{X}: 40.71)$, kontrol grubundaki öğrencilerin öntest puan ortalamaları ( $\bar{X}: 43,57)$ arasında istatistiksel olarak anlamlı bir fark yoktur. Bu sonuçlara göre kontrol ve deney gruplarının 2019-2020 eğitim öğretim yılı 1. dönem Türkçe ortalama puanlarında olduğu gibi söz sanatları başarı testi sonuçları bakımından da benzer düzeyde olduğu ortaya çıkmıştır.

\section{İkinci Alt Probleme ílişkin Bulgular}

Söz sanatlarının karikatürdeki kırılma çizgileri ile ilişkilendirilerek işlendiği deney grubu ile geleneksel öğretim yönteminin uygulandığı kontrol grubunun sontest puan ortalamaları arasındaki farklııık Tablo 6' da gösterilmiştir. 
Tablo 6.

Deney ve Kontrol Grupları Sontest Puan Ortalamaları

\begin{tabular}{lllllllll}
\hline Grup & $\mathrm{N}$ & Mean & Std. Sapma & Std. Hata Ort. & $\mathrm{T}$ & $\mathrm{df}$ & $\mathrm{p}$ \\
\hline Deney & 14 & 59,29 & 27,023 & 7,222 & 1,348 & 26 &, 189 \\
Kontrol & 14 & 47,14 & 20,164 & 5,389 & & & \\
\hline
\end{tabular}

Tablo 6'da deney ve kontrol grubunda yer alan öğrencilerin sontestten aldıkları puan ortalamaları arasındaki farklılaşmayı tespit etmek için yapılan bağımsız örneklemler grubu t testi sonuçları mevcuttur. Deney ve kontrol grubunda yer alan öğrencilerin sontestten aldıkları puan ortalamaları anlamlı bir şekilde farklılaşmamaktadır ( $\mathrm{t}: 1,348, \mathrm{p}>.05)$. Deney grubundaki öğrencilerin sontest puan ortalamaları ( $\overline{\mathrm{X}}: 59.29)$,kontrol grubundaki öğrencilerin sontest puan ortalamaları $(\overline{\mathrm{X}}: 47,14)$ arasında istatistiksel olarak anlamlı bir fark yoktur. Deney ve kontrol grubunda yer alan öğrencilerin sontestten aldıkları puan ortalamaları arasındaki farkın büyüklüğünü anlamak için istatistiksel anlamlılığın yanı sıra etki büyüklüğü de hesaplanmıştır. Yapılan değerlendirme sonucu $[d=2 t / v(d f)]$ "Cohen $d$ " indeksi (d: 0,52, d >0,5) orta etki olarak tespit edilmiştir.

\section{Üçüncü Alt Probleme iliş̧kin Bulgular}

Söz sanatlarının karikatürdeki kırılma çizgileri ile ilişkilendirilerek işlendiği deney grubunun önsontest puan ortalamaları arasındaki farklılık öncesinde puan ortalamalarının normal dağılım gösterip göstermediği incelenmiştir. Kolmogorov-Smirnov testi sonuçları değerlendirilmiş, örneklem sayısı 28 kişi olduğu için Shapiro-Wilk sonuçlarına bakılmış; deney grubunun öntest-sontest puan ortalamaları anlamlılık değeri $(p>0.05)$ olduğundan verilerin normal dağılıma uygun olduğu tespit edilerek Tablo 7'de gösterilmiştir.

Tablo 7.

Deney Grubu Öntest-Sontest Puan Ortalamaları Normallik Testi

\begin{tabular}{llllllll} 
& \multicolumn{3}{l}{ Kolmogorov-Smirnov } & \multicolumn{3}{l}{ Shapiro-Wilk } \\
\cline { 2 - 8 } & Statistic & df & Sig. & Statistic & df & Sig. \\
\hline Toplam Puan Öntest &, 246 & 14 &, 021 &, 945 & 14 &, 489 \\
Toplam Puan Sontest &, 132 & 14 &, 200 &, 960 & 14 &, 716 \\
\hline
\end{tabular}

Söz sanatlarının karikatürdeki kırılma çizgileri ile ilişkilendirilerek işlendiği deney grubunun öntest-sontest puan ortalamaları arasındaki farklııık Tablo 8'de gösterilmiştir.

Tablo 8.

Deney Grubu Öntest-Sontest Puan Ortalamalarının Farklılaşmasını Gösteren Bağımlı Örneklem Grubu $t$ Testi Sonuçları

\begin{tabular}{llllllll}
\hline & $\mathrm{N}$ & a & Std. Sapma & Std. Hata Ort. & $\mathrm{t}$ & $\mathrm{df}$ & $\mathrm{p}$ \\
\hline Toplam Puan Ön Test & 14 & 40,7143 & 23,68521 & 6,33014 & $-3,139$ & 13 &, $008^{*}$ \\
Toplam Puan Son Test & 14 & 59,2857 & 27,02258 & 7,22209 & & &
\end{tabular}

$* p<0.05$

Tablo 8'de deney grubunda yer alan öğrencilerin öntest ve sontestten aldıkları puan ortalamaları arasındaki farklılaşmayı tespit etmek için yapılan bağımlı örneklemler grubu t testi sonuçları mevcuttur. Deney grubunda yer alan öğrencilerin öntest ve sontestten aldıkları puan ortalamaları anlamlı bir şekilde farklılaşmaktadır (t:-3,139, p<.05). Deney grubundaki öğrencilerin öntest puan ortalamaları ( $\bar{X}: 40.71)$, ile öğrencilerin sontest puan ortalamalarına $(\bar{X}: 59,28)$ göre istatistiksel olarak anlamlı bir biçimde daha yüksektir. Deney grubunda yer alan öğrencilerin öntest ve sontestten aldıkları puan ortalamaları arasındaki farkın büyüklüğünü anlamak için istatistiksel 
anlamlılığın yanı sıra etki büyüklüğü de hesaplanmıştır. Yapılan değerlendirme sonucu $[d=t / v(N)]$ "Cohen d" indeksi (d: 0,83, d>0,8) büyük etki olarak tespit edilmiştir.

\section{Dördüncü Alt Probleme iliş̧kin Bulgular}

Geleneksel öğretim yönteminin uygulandığı kontrol grubunun ön-sontest puan ortalamaları arasındaki farklııı öncesinde puan ortalamalarının normal dağılım gösterip göstermediği incelenmiştir. Kolmogorov-Smirnov testi sonuçları değerlendirilmiş, örneklem sayısı 28 kişi olduğu için Shapiro-Wilk sonuçlarına bakılmış; deney grubunun öntest-sontest puan ortalamaları anlamlılık değeri sontestte $(p<0.05)$ olduğundan verilerin normal dağılıma uygun olmadığı tespit edilerek Tablo $9^{\prime}$ da gösterilmiştir.

Tablo 9.

Kontrol Grubu Öntest-Sontest Puan Ortalamaları Normallik Testi

\begin{tabular}{ll|l|l|l|l|l} 
& \multicolumn{3}{l}{ Kolmogorov-Smirnov } & \multicolumn{3}{l}{ Shapiro-Wilk } \\
\cline { 2 - 8 } & Statistic & df & Sig. & Statistic & df & Sig. \\
\hline Toplam Puan Öntest &, 159 & 14 &, 200 &, 908 & 14 &, 147 \\
Toplam Puan Sontest &, 210 & 14 &, 096 &, 825 & 14 &, 010 \\
\hline
\end{tabular}

Geleneksel öğretim yönteminin uygulandığı kontrol grubunun ön-sontest puan ortalamaları arasındaki farklıık verilerin normal dağılım göstermemesi üzerine Wilcoxon işaretli sıralar testi yapılmış ve Tablo 10'da gösterilmiştir.

Tablo 10.

Kontrol Grubu Öntest-Sontest Puan Ortalamalarının Farklılaşmasını Gösteren Wilcoxon Işsaretli Sıralar Testi Sonuçları

\begin{tabular}{llllll}
\hline & $\mathrm{N}$ & Sıra Ortalaması & Sıralar Toplamı & $\mathrm{z}$ & $\mathrm{p}$ \\
\hline Toplam Puan Ön Test & 14 & 4,50 & 22,50 &,- 955 &, $340^{*}$ \\
Toplam Puan Son Test & 14 & 7,25 & 43,50 & &
\end{tabular}

${ }^{*} p<0.05$

Tablo $10^{\prime}$ da kontrol grubunda yer alan öğrencilerin öntest ve sontestten aldıkları puan ortalamaları arasındaki farklılaşmayı tespit etmek için yapılan Wilcoxon işaretli sıralar testi sonuçları mevcuttur. Kontrol grubunda yer alan öğrencilerin öntest ve sontestten aldıkları puan ortalamaları anlamlı bir şekilde farklılaşmamaktadır (z:-,955, p>.05). Kontrol grubunda yer alan öğrencilerin öntest ve sontestten aldıkları puan ortalamaları arasındaki farkın büyüklüğünü anlamak için istatistiksel anlamlıı̆ı̆ın yanı sıra etki büyüklüğü de hesaplanmıştır. Yapılan değerlendirme sonucu $[d=z / V(N)]$ "Cohen d" indeksi (d: 0,24, d>0,2) küçük etki olarak tespit edilmiştir.

\section{Beşinci Alt Probleme ilişkin Bulgular}

Araştırmanın beşinci alt probleminde araştırmanın ilk dört alt probleminden elde edilen verileri desteklemek amacıyla birkaç sorudan oluşan yarı yapılandırılmış görüşme formu hazırlanmıştır. Görüşme formunda öğrencilere "Söz sanatlarının karikatürdeki kırılma çizgileri ile ilişkilendirilerek işlendiği süreçle ilgili duygu ve düşünceleri ve daha önceki Türkçe dersleri ile söz sanatlarının karikatürdeki kırılma çizgileri ile ilişkilendirilerek işlendiği Türkçe derslerini karşılaştırdıklarında sürece dair olumlu ve olumsuz düşünceleri sorulmuş ve bu görüşler, tema ve alt temalara ayrılmıştır: Araştırmanın beşinci alt problemi için elde edilen bulgular, Tablo 11'de gösterilmiştir. 
Tablo 11.

Öğrencilerin Söz Sanatlarının Karikatürdeki Kırılma Çizgileri ile ilişskilendirilerek İşlendiği Süreçle ilgili Görüşleri

\begin{tabular}{|c|c|c|}
\hline Kategori & Alt Kategori & Örnek Açıklama \\
\hline \multirow[t]{2}{*}{$\begin{array}{l}\text { Uygulama } \\
\text { Süreciyle IIlgili } \\
\text { Görüşler }\end{array}$} & $\begin{array}{l}\text { Eğlenerek } \\
\text { Öğrenme }\end{array}$ & $\begin{array}{l}\text { Ö1: Söz sanatlarını öğrendim hem de eğlendim. Sıkılmadım. } \\
\text { Ö2: Ben çok eğlendim. Özellikle karikatürlere çok güldüm. } \\
\text { Karikatürler sayesinde güldüm, eğlendim. } \\
\text { Ö4: Öğretmenim derste karikatürler açtı, karikatürlere güldüm, } \\
\text { çok eğlendim. Söz sanatlarını da anladım. } \\
\text { Ö5: Hem karikatürü okuyup güldük hem de söz sanatlarını } \\
\text { öğrendik. } \\
\text { Ö6: Öğretmenimin konuyla ilgili gösterdiği karikatürler çok } \\
\text { komikti. Öğrenip eğleniyoruz artık. Tam istediğim gibi. Eğlen, } \\
\text { öğren. Öğren, eğlen. }\end{array}$ \\
\hline & $\begin{array}{l}\text { Başarıyı ve } \\
\text { Kalıcılığı Artırma }\end{array}$ & $\begin{array}{l}\text { Ö1: Kolay kolay unutmam artık. Mesela yaşlının telefona bakan } \\
\text { genci karşıya geçirmesi zıtlıktı. Zıtlı̆ı unutunca bu karikatür } \\
\text { aklıma gelir ben de hatırlarım. } \\
\text { Ö2: Söz sanatları aklıma gelmezse öğretmenimin gösterdiği } \\
\text { karikatürden hatırlarım. Unutmam. Yazılıda kolayca hatırlarım, } \\
\text { soruyu doğru yaparım. } \\
\text { Ö7: Söz sanatları konusu aklımda daha iyi kaldı. Karikatür } \\
\text { sayesinde unutmayabilirim. }\end{array}$ \\
\hline \multirow[t]{2}{*}{$\begin{array}{l}\text { Uygulama } \\
\text { Öncesini ve } \\
\text { Sonrasına Dair } \\
\text { Olumlu ve } \\
\text { Olumsuz } \\
\text { Düşünceler }\end{array}$} & $\begin{array}{l}\text { Ders Kitabındaki } \\
\text { Etkinliklerle } \\
\text { Kıyaslama }\end{array}$ & $\begin{array}{l}\text { Ö2: Ders kitabındaki sıkıcı etkinliklerden kurtulduk. } \\
\text { Karikatürlerle daha güzel oldu ders. } \\
\text { Ö3: Etkinliklerde karikatür olunca Türkçe kitabından kurtulduk. } \\
\text { Karikatürlerle ders işledik. } \\
\text { Ö7: Öğretmenimin gösterdiği karikatürler çok komikti. Diğer } \\
\text { derslerde etkinlikler sıkıcı. Gülmüyordum bu kadar. }\end{array}$ \\
\hline & İlgiyi Artırma & $\begin{array}{l}\text { Ö5: Çok gürültü oldu. Konuyu sevdim ama sınıf çok bağırdı, } \\
\text { karikatürleri anlamak için. Karikatürlü dersleri gürültü olmasa } \\
\text { sevebilirim; başarım da artar. } \\
\text { Ö2: Karikatürlü dersleri çok sevdim. Tüm derslerimiz karikatürlü } \\
\text { olabilir. } \\
\text { Ö1: Ben öğretmen olsam tüm dersleri karikatürle anlatırım. } \\
\text { Çocuklar dersleri daha çok sever. }\end{array}$ \\
\hline
\end{tabular}

Araştırmanın beşinci alt problemi için hazırlanan yarı yapılandırılmış görüşme formundaki öğrenci görüşleri kategorilere ayrıldığında temelde Uygulama Süreci ile ilgili Görüşler ve Uygulama Öncesini ve Sonrasına Dair Olumlu ve Olumsuz Düşünceler olmak üzere iki kategori öne çıkmaktadır.

Öğrencilerin uygulama süreci ile ilgili görüşlerine baktığımızda bu görüşlerin iki farklı alt kategoride toplandığı görülmektedir.

Bu alt kategorilerden ilki "Eğlenerek Öğrenme"dir. Katılımcılar, söz sanatlarının öğretiminde karikatürdeki kırıma çizgilerinin kullanıldığı süreçte hem öğrendiklerini hem de karikatürün mizahi yönünün etkisiyle eğlendiklerini dile getirmektedir.

Uygulama süreci ile ilgili görüşlerden hareketle oluşturulan ikinci alt kategori "Başarıyı ve Kalıcılığı Artırma"dır. Katılımcılar, söz sanatlarının öğretiminde karikatürdeki kırılma çizgilerinin kullanılmasının konuyla ilgili başarılarını artırdığını bununla birlikte öğrendiklerinin de kalıcı olacağını dile getirmektedir.

Öğrencilerin uygulama öncesine ve sonrasına dair olumlu ve olumsuz düşüncelerle ilgili görüşlerine baktığımızda bu görüşlerin iki farklı alt kategoride toplandığı görülmektedir. 
Bu alt kategorilerden ilki "Ders Kitabındaki Etkinliklerle Kıyaslama"dır. Katılımcılar, söz sanatlarının öğretiminde karikatürdeki kırılma çizgilerinin kullanıldığı süreçteki etkinlikleri karikatürle desteklendiği için ders kitabındaki etkinliklere göre daha eğlenceli ve ilgi çekici bulmuştur.

Uygulama öncesine ve sonrasına dair olumlu ve olumsuz düşüncelerle ilgili görüşlerden hareketle oluşturulan ikinci alt kategori "ilgiyi Artırma"dır. Katılımcılar, söz sanatlarının öğretiminde karikatürdeki kırıma çizgilerinin kullanılmasının konuya ve Türkçe dersine olan ilgilerini artıracağını dile getirmektedir.

\section{Tartışma ve Sonuç}

Temel dil becerileri ile söz sanatları arasındaki ilişkiye, anlama ve anlatma çalışmaları noktasında büyük önem taşımasına rağmen alanyazın tarandığında Türkçe dersinde söz sanatlarının öğretimi ile ilgili araştırmaların sınırlı sayıda olduğu görülmektedir.

Bayir (2018) söz sanatlarının öğretimine dair çalışmasında söz sanatlarının öğretiminde Nef'î'nin divanının kullanılıp kullanılamayacağı sorusuna cevap aramıştır; Uludağ (2018), söz sanatlarının öğretiminde yaratıcı dramadan yararlanabileceğini belirtmiştir. Coşar (2005) da ortaöğretimde söz sanatlarının öğretiminde görsel materyallerden yararlanarak söz sanatlarının öğretilebileceğini vurgular. Akkuş (2011) ise simgesel dil kullanımından faydalanılabileceğini ortaya koymaktadır.

Çalışmada deney ve kontrol grubunda yer alan öğrencilerin öntestten aldıkları puan ortalamaları anlamlı bir şekilde farklılaşmadığı görülmüştür. Deney ve kontrol grubunda yer alan öğrencilerin sontestten aldıkları puan ortalamaları anlamlı bir şekilde farklılaşmamakla birlikte deney grubundaki öğrencilerin sontest puan ortalamaları ( $\bar{X}: 59.29)$, kontrol grubundaki öğrencilerin sontest puan ortalamaları $(\bar{X}: 47,14)$ arasında 12 puanlık bir fark olduğu; etki büyüklüğünün de orta etki olduğu tespit edilmiştir.

Söz sanatlarının karikatürdeki kırılma çizgileri ile ilişkilendirilerek işlendiği deney grubunda yer alan öğrencilerin öntest ve sontestten aldıkları puan ortalamaları anlamlı bir şekilde farklılaşmaktadır, uygulama sonrası deney grubundaki öğrencilerin öntest puan ortalamaları ile sontest puan ortalamaları arasında 19 puanlık bir fark olduğu görülmüştür. Yapılan değerlendirme sonucu "Cohen $d^{\prime \prime}$ indeksi (d: 0,83, $\left.d>0,8\right)$ büyük etki olarak tespit edilmiştir.

Geleneksel öğretim yönteminin uygulandığı kontrol grubunda yer alan öğrencilerin öntest ve sontestten aldıkları puan ortalamaları anlamlı bir şekilde farklılaşmamıştır. Etki büyüklüğü yapılan değerlendirme sonucu "Cohen $d$ " indeksi ( $d: 0,24, d>0,2)$ küçük etki olarak tespit edilmiştir.

Deney grubundaki öğrencilerin uygulamayla ilgili görüşleri için hazırlanan yarı yapılandırıımış görüşme formundaki öğrenci görüşlerinin Uygulama Süreci ile ilgili Görüşler ve Uygulama Öncesini ve Sonrasına Dair Olumlu ve Olumsuz Düşünceler olmak üzere iki kategoride toplandığl; uygulama süreci ile ilgili görüşlerin "Eğlenerek Öğrenme" ve "Başarıyı ve Kalıcılı̆ı Artırma" olmak üzere iki farklı alt kategoride toplandığı; uygulama öncesine ve sonrasına dair olumlu ve olumsuz düşüncelerle ilgili görüşlerin de "Ders Kitabındaki Etkinliklerle Kıyaslama" ve "ilgiyi Artırma" olmak üzere iki farklı alt kategoride toplandığı görülmüştür.

Bu sonuçlar söz sanatlarının öğretiminde karikatürün, sahip olduğu kırılma çizgilerinin de etkisiyle, kullanılabileceğini göstermiştir. Bu nedenle Türkçe öğretmenleri, söz sanatlarının öğretiminde karikatürdeki kırılma çizgilerinden faydalanmalıdır; eğitim öğretim faaliyetleri sırasında karikatürün etkisini göz ardı etmemelidir. Yine ders kitabı yazarlarının da oluşturacakları etkinliklerde karikatürdeki kırılma çizgilerinden faydalanmalarının konunun anlaşılmasını kolaylaştıracağı gibi kalıcılı̆̆ını da sağlayacağı anlaşımaktadır.

Diğer yandan çalışmanın sonuçlarını sınırlayan birtakım faktörler bulunmaktadır. Bu sebeple araştırmanın sonuçlarını genellemek mümkün görünmemektedir. Bu sınırlayıcı faktörlerden ilki çalışmanın Afyonkarahisar ilindeki bir ortaokulda ve 6 . sınıftaki 28 öğrenciyle yürütülmesidir. Bu bağlamda söz konusu çalışmanın bir benzeri 5,7 ve 8 . sınıflar özelinde ya da ortaöğretim düzeyinde ve farklı illerde yürütülebilir. Böylece çalışmanın sonuçları daha sağlıklı değerlendirilebilecektir. 


\section{Kaynaklar}

Akkaya, A. (2011). Karikatürlerle Dil Bilgisi Öğretimi. Doktora Tezi. Konya, Türkiye: Selçuk Üniversitesi Eğitim Bilimleri Enstitüsü Türkçe Eğitimi Ana Bili Dalı Türkçe Eğitimi Bilim Dalı.

Akkuş, R. (2011). Türkçe Dersinde Simgesel Dil Öğretiminin İlköğretim Öğrencilerinin Benzetme Kişileştirme ve Deyim Kullanımına Etkisi. Yayımlanmamış Yüksek Lisans Tezi. Eskişehir: Osmangazi Üniversitesi.

Akran, S. K., \& Kocaman, i. (2018). The Effect of Caricature Based Learning-Teaching Model on PreSchool Students' Speaking and Listening Skills. E-International Journal of Educational Research, 9(2), 105-122.

Aksan, D. (2001). Türkçenin Söz Varlı̆̆ı. Ankara: Engin Yayınevi.

Aktaş, H. (2002). Modern Türk Şiirinde Edebî Sanatlar. Konya: Söylem Yayınları.

Ana Britannica . (1994). Genel Kültür Ansiklopedisi. İstanbul: Ana Yayıncılık.

Aslan, C., Güldenoğlu, B. N., \& Altuntaş, i. (2018). Türkçe Ders Kitaplarındaki Söz Sanatlarıyla Illgili Sorular ve Etkinlikler Üzerine Bir İnceleme. Turkish Studies, 13(28), 47-66.

Aşıcıoğlu, E. A. (2001). Yazısız Karikatürlerin Grafik Sanatındaki Yeri, Yazısız Karikatür Uygulamaları. Yayınlanmamış Yüksek Lisans Tezi. Ankara: Hacettepe Üniversitesi Sosyal Bilimler Enstitüsü.

Baki, A., \& Gökçek, T. (2012). Karma Yöntem Araştırmalarına Genel Bir Bakış. Elektronik Sosyal Bilimler Dergisi, 11(42), 1-21.

Bayir, M. (2018). Söz Sanatları Öğretiminde Nef'î'nin Türkçe Divanı. Yüksek Lisans Tezi. Ankara: Gazi Üniversitesi Eğitim Bilimleri Enstitüsü Sosyal Bilgiler ve Türkçe Eğitimi Anabilim Dalı.

Betur, M. (2019). Ortaöğretim Öğrencilerinin Söz Sanatlarına ve Söz Sanatları Öğretimine Yönelik Görüşleri. Yayımlanmamış Yüksek Lisans Tezi. Ankara: Ankara Üniversitesi Eğitim Bilimleri Enstitüsü.

Bilgin, M. (2013). Anlamdan Anlatıma Türkçemiz. Ankara: Anı Yayıncılık.

Büyüköztürk, Ş., Kılıç Çakmak, E., Akgün, Ö. E., Karadeniz, Ş., \& Demirel, F. (2018). Bilimsel Araştırma Yöntemleri (24. b.). Ankara: Pegem Akademi .

Coşar, S. (2005). Ortaöğretim Birinci Sınıfta Türk Dili ve Edebiyatı Dersinde Edebi Sanatlar ve Öğretimi. Yayımlanmamış Yüksek Lisans Tezi. Çanakkale: Çanakkale Onsekiz Mart Üniversitesi Sosyal Bilimler Enstitüsü.

Çotuksöken, Y. (2012). Türkçe Dil ve Edebiyat Terimleri Sözlügü. İstanbul: Papatya Yayınları.

Efe, H. (2005). Karikatür ve Eğitim. İzmir: Etki Yayınları.

Ekergil, i. (2000, Ağustos). Zihin Engelli Çocuklara Zıtlık Kavramlarını Öğretmede Doğal Dille Uygulanan Doğrudan Öğretim Yönteminin Etkililiği. Yaınlanmamış Yüksek Lisans Tezi. Eskişehir: Anadolu Üniversitesi Eğitim Bilimleri Enstitüsü.

EKOYAY. (2019). Ortaokul ve Imam Hatip Ortaokulu Türkçe 6. Sınıf Ders Kitabı. Ankara: EKOYAY Eğitim Yayıncilık.

Güneş, F. (2017). Türkçe Öğretiminde Etkinlik Yaklaşımı. Ana Dili Eğitimi Dergisi, 5(1), 48-64.

Hawk, T. F., \& Shah, A. J. (2007). Using Learning Style Instruments to Enhance Student Learning. Decision Sciences Journal of Innovative, 5(1), 1-19.

Hünerli, S. (1993). Türkiye'de Gazete Karikatürünün Durumu ve Siyasi Karikatürün Söylemi. Yayınlanmamış Yüksek Lisans Tezi. İstanbul: İstanbul Üniversitesi Sosyal Bilimler Enstitüsü.

Kelley, M. (1989). Foul Perfection: Thoughts on Caricature. Artforum, 27(5), 20-38.

Keogh, B., \& Naylor, S. (1999). Concept Cartoons, Teaching and Learning in Science: An Evaluation. International Journal of Science Education, 21(4), 431-446.

Kocakaplan, i. (1992). Açıklamalı Edebî Sanatlar. İstanbul: MEB Yayınları.

Marshall, M. (1996). Sampling For Qualitative Research. Family Practice, 13(6), 522-526.

MEB. (2019). Türkçe Dersi Öğretim Programı. Nisan 11, 2020 tarihinde Öğretim Programları: http://mufredat.meb.gov.tr/Dosyalar/20195716392253-02-

T\%C3\%BCrk\%C3\%A7e\%20\%C3\%96\%C4\%9Fretim\%20Program\%C4\%B1\%202019.pdf adresinden alındı

Onan, B. (2013). Dil Eğitiminin Temel Kavramları. Ankara: Nobel Yayın Dağıtım. 
Örs, F. (2006). Eğitim ve Karikatür. Bilim ve Aklın Aydınlığında Eğitim Dergisi, 84, 26-28.

Özden, Y. (2005). Öğrenme ve Öğretme (7. b.). Ankara: Pegema Yayınları.

Seçgin, F., Yalvaç, G., \& Çetin, T. (2010). illköğretim 8. Sınıf Öğrencilerinin Karikatürler Aracılığıyla Çevre Sorunlarına ilişskin Algıları. International Conference on New Trends in Education and Their Implications, 11(13), 391-398.

Strauss, A., \& Corbin, J. (2008). Basics of Qualitative Research: Second Edition: Techniques and Procedures for Developing Grounded Theory. Los Angeles: Sage Publications.

Şeref, i.., \& Yılmaz, i. (2015). Yemenli Öğrencilerin Türkçe Yazma ve Konuşma Becerilerinin Geliştirilmesinde Karikatür Kullanımına Yönelik Bir Uygulama. Turkish Studies, 10(7), 835-860.

Uludağ, M. (2018). Edebi Sanatların Öğretiminde Yaratıcı Drama Etkinliklerinin Öğrenci Başarısına Etkisi. Yayınlanmamış Yüksek Lisans Tezi. Burdur: Mehmet Akif Ersoy Üniversitesi Eğitim Bilimleri Enstitüsü.

Varışoğlu, B., Şeref, i., Gedik, M., \& Yılmaz, i. (2014). The Effect of Cartoons as a Visual Tool in the Success of Teaching Idioms and Proverbs. Journal of The Black Sea Studies, 41, 226-242.

Wyk, M. M. (2011). The Use of Cartoons as a Teaching Tool to Enhance Student Learning in Economics Education. Journal of Social Science, 26(2), 117-130.

\section{Introduction}

\section{Extended Abstract}

Visual stimuli are frequently preferred during educational activities as they enable individuals to take an active role in the learning process by affecting several sensory organs at the same time. At this point, one of the visual stimuli that can be used as a material in Turkish education is cartoons. It is seen that instead of knowing the rules of the vocal arts that directly contribute to the meaning of the text, and determining the art of the vocabulary in the text, students need activities and materials that will realize the effect of the vocal arts on understanding. The importance of the study comes to the fore at this point. In the study, it was aimed to determine the effect of the breaking lines that form the basis of the cartoons in the teaching of the speech arts.

In this way, instead of the traditional methods used in the teaching of speech arts, it will increase the motivation of the students by attracting the attention of the students, and cartoons in the position of more functional material will be used as lesson material, which will prevent the subject of speech to remain at the level of knowledge and definition and ensure that its knowledge and skills are permanent. In the study, whether there is a significant difference between the pretest and posttest mean scores of the experimental group and the control group, in which the vocal arts are associated with the break lines in the cartoon, and the control group where the traditional teaching method is applied, in order to determine the effect of the breaking lines that form the basis of the cartoons. whether there is a difference, whether there is a significant difference between the pre-posttest test mean scores of the control group, the opinions of the experimental group students about the process were examined.

\section{Method}

In this study, qualitative supported quantitative research design was used to determine the effect of the breaking lines that form the basis of cartoons in the teaching of the verbal arts. In this pattern, which is called the complementary mixed pattern, it is also essential to make use of the results of the qualitative pattern in the sense of the findings obtained from the quantitative pattern. While interpreting the findings in the complementary mixed pattern, those obtained from one pattern are used to support the results of the other pattern.

For the quantitative dimension of the study, the pretest-posttest paired control group pattern, which is one of the experimental research methods, is used as a requirement of the nature of the research. For the qualitative dimension, the opinions of the students selected from the experimental group regarding the process were taken. 


\section{Result and Discussion}

In the study, it was observed that the mean scores of the students in the experimental and control groups did not differ significantly from the pretest. Although the average scores of the students in the experimental and control groups did not differ significantly from the posttest, there was a 12point difference between the posttest mean scores of the students in the experimental group (]: 59.29) and the posttest mean scores of the students in the control group (回: 47.14); It has been determined that the effect size is also medium effect.

The mean scores of the students in the experimental group, in which the verbal arts are associated with the breaking lines in the cartoon, differ significantly from the pre-test and post-test scores, and there was a 19-point difference between the pre-test mean scores and the post-test mean scores of the students in the experimental group. As a result of the evaluation, "Cohen $d$ " index (d: $0.83, \mathrm{~d}>0.8$ ) was determined as a major effect.

The mean scores of the students in the control group, where the traditional teaching method is applied, from the pretest and posttest did not differ significantly. "Cohen $d$ " index (d: 0.24, $d>0.2$ ) was determined as a small effect after the effect size assessment.

In the semi-structured interview form prepared for the opinions of the students in the experimental group, the opinions of the students were gathered in two categories: Opinions about the Application Process and Positive and Negative Thoughts about the Pre and Post Application; opinions about the application process are gathered in two different sub-categories: "Learning by Fun" and "Increasing Success and Persistence"; It was observed that the opinions about the positive and negative thoughts about before and after the application were gathered in two different subcategories: "Comparison with the Activities in the Textbook" and "Increasing Interest".

These results showed that cartoon can be used in the teaching of speech arts with the effect of its breaking lines. For this reason, Turkish teachers should benefit from the breaking lines in cartoons in the teaching of speech arts; should not ignore the effect of caricature during educational activities. It is also understood that the use of the breaking lines in the cartoons in the activities to be created by the textbook authors will not only facilitate the understanding of the subject, but also ensure its permanence. 
Ekler

Ek-1. Ders Planı

DERS PLANI TASLAĞI

Bölüm I

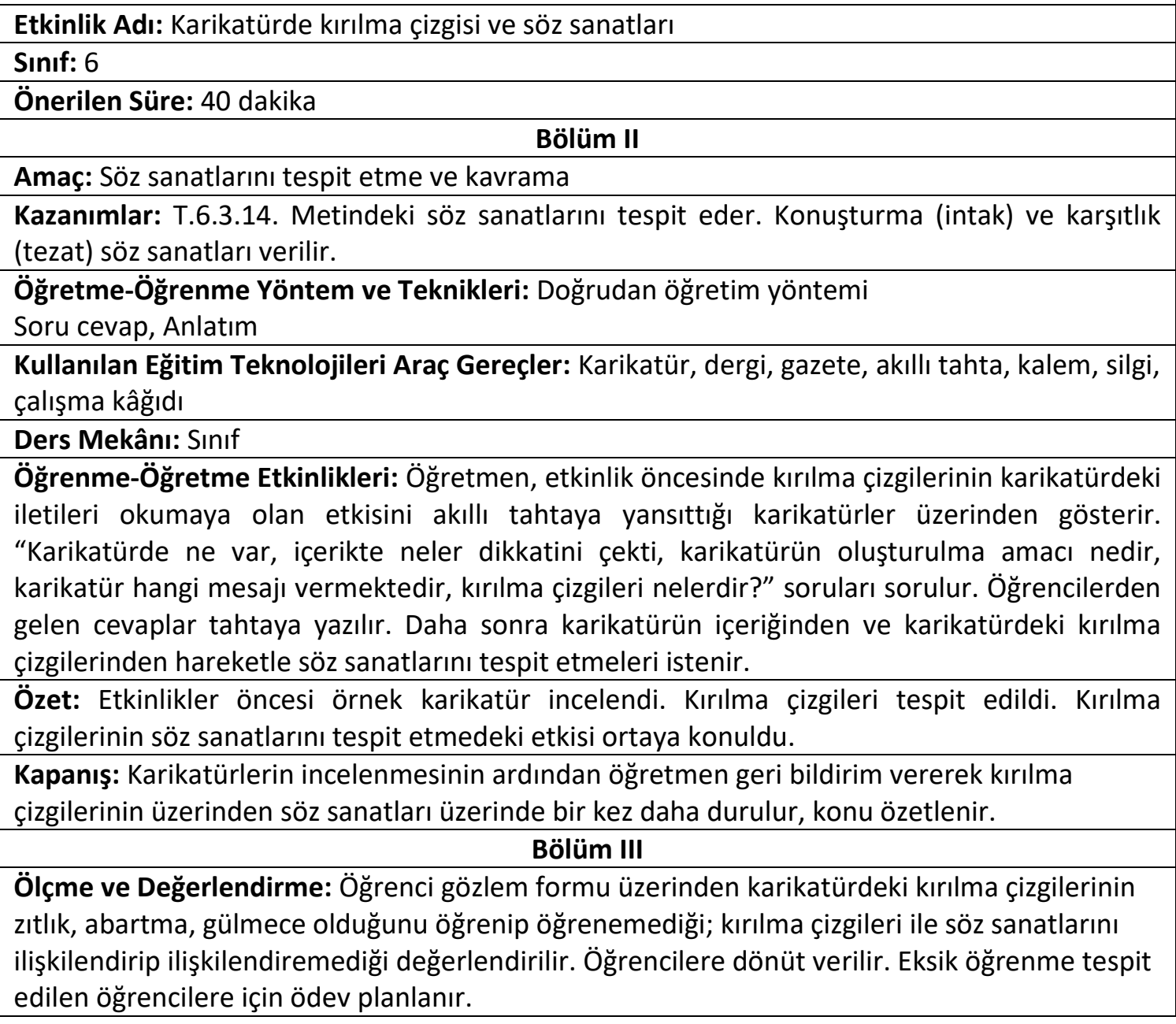


Ek-2. Etkinlik Örneği

Etkinlik-D1

1.Aşağıda verilen karikatürleri inceleyiniz. Ardından karikatürde yer alan kırılma çizgilerini ve söz sanatlarını tespit ediniz.

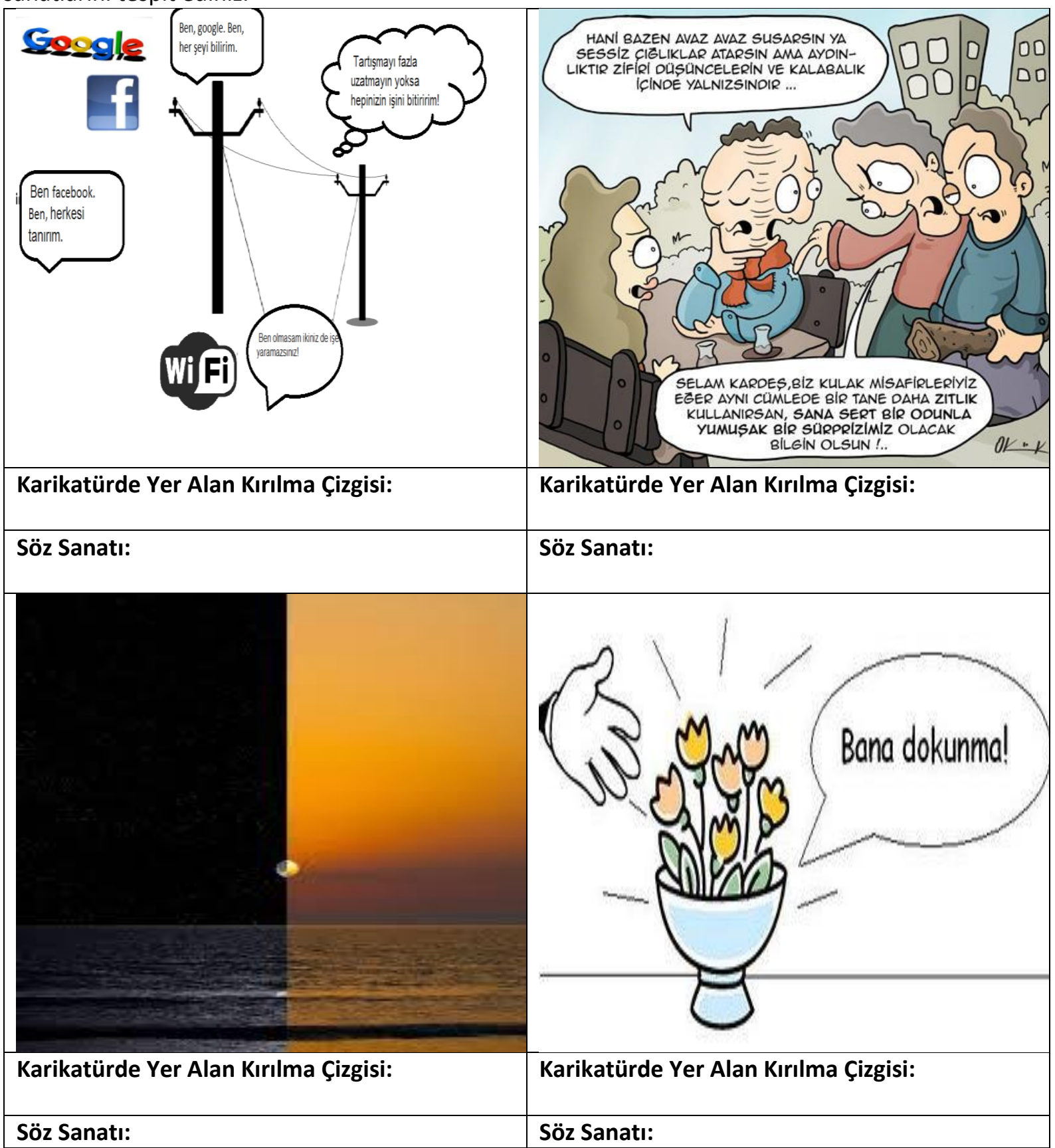

